\title{
Tissue Microenvironments Define and Get Reinforced by Macrophage Phenotypes in Homeostasis or during Inflammation, Repair and Fibrosis
}

\author{
Marc Weidenbusch Hans-Joachim Anders \\ Medizinische Klinik IV, Klinikum der Universität München-LMU, München, Deutschland
}

\section{Key Words}

Toll-like receptors $\cdot$ Pathology $\cdot$ Leukocytes $\cdot$ Polarization • Ischemia $\cdot$ Wound healing

\begin{abstract}
Current macrophage phenotype classifications are based on distinct in vitro culture conditions that do not adequately mirror complex tissue environments. In vivo monocyte progenitors populate all tissues for immune surveillance which supports the maintenance of homeostasis as well as regaining homeostasis after injury. Here we propose to classify macrophage phenotypes according to prototypical tissue environments, e.g. as they occur during homeostasis as well as during the different phases of (dermal) wound healing. In tissue necrosis and/or infection, damage- and/or pathogen-associated molecular patterns induce proinflammatory macrophages by Toll-like receptors or inflammasomes. Such classically activated macrophages contribute to further tissue inflammation and damage. Apoptotic cells and antiinflammatory cytokines dominate in postinflammatory tissues which induce macrophages to produce more antiinflammatory mediators. Similarly, tumor-associated macrophages also confer immunosuppression in tumor stroma. Insufficient parenchymal healing despite abundant growth
\end{abstract}

factors pushes macrophages to gain a profibrotic phenotype and promote fibrocyte recruitment which both enforce tissue scarring. Ischemic scars are largely devoid of cytokines and growth factors so that fibrolytic macrophages that predominantly secrete proteases digest the excess extracellular matrix. Together, macrophages stabilize their surrounding tissue microenvironments by adapting different phenotypes as feed-forward mechanisms to maintain tissue homeostasis or regain it following injury. Furthermore, macrophage heterogeneity in healthy or injured tissues mirrors spatial and temporal differences in microenvironments during the various stages of tissue injury and repair.

Copyright $\odot 2012$ S. Karger AG, Basel

\section{Introduction}

Defined cytokine stimuli induce different and distinct macrophage phenotypes in vitro [1]. The inconsistency between in vitro macrophage studies and the heterogeneity of tissue macrophages in vivo should relate to their phenotype plasticity in complex microenvironments which are not adequately mimicked by in vitro conditions [2]. As such in vivo studies never really display clear macrophage phenotypes according to the M1/M2 paradigm

\section{KARGER \\ Fax +41613061234 \\ E-Mail karger@karger.ch}

www.karger.com
(C) 2012 S. Karger AG, Basel

$1662-811 \mathrm{X} / 12 / 0046-0463 \$ 38.00 / 0$

Accessible online at:

www.karger.com/jin
Dr. Hans-Joachim Anders

Medizinische Poliklinik der LMU

Pettenkoferstrasse $8 \mathrm{a}$

DE-80336 München (Germany)

Tel. +4989218075 855, E-Mail hjanders@med.uni-muenchen.de 
Table 1. Resident macrophages and dendritic cells in various tissues

\begin{tabular}{lll}
\hline Organs/cell types & Dendritic cells & Macrophages \\
\hline $\begin{array}{ll}\text { Skin } \\
\text { Brain }\end{array}$ & Dermal DCs, Langerhans cells [3] & $\begin{array}{l}\text { Dermal macrophages [3] } \\
\text { Microglia [3] }\end{array}$ \\
Lung & & Alveolar macrophages [3] \\
Stomach & Lamina propria DCs [59] & Intestinal macrophages [59] \\
Ileum & Lamina propria DCs [59] & Intestinal macrophages [59] \\
Colon & Lamina propria DCs [59] & Intestinal macrophages [59] \\
Liver & Plasmacytoid DCs, cDCs [130] & Kupffer cells [3] \\
Spleen & iDCs, follicular DCs [131] & Marginal zone macrophages, \\
& & red pulp macrophages [3] \\
Pancreas & Dendritic cell precursors [132] & \\
Kidney & Interstitial DCs [133, 134] & \\
Ovary/testis & & Ovarian macrophages [109] \\
Bone marrow & & Bone marrow macrophages [135] \\
Bone & & Osteoclasts [3]
\end{tabular}

DCs $=$ Dendritic cells.

[1-3]. An understanding of this issue also involves the question of whether primed macrophages alter tissues or whether tissues use macrophage differentiation to meet tissue needs, a chicken-or-egg question?

Terminology including the likes of 'host defense', 'immune effector cells' or 'collateral inflammatory tissue damage' represent the underlying concept of the stranger hypothesis [4] which implies that the immune system is in control of tissue damage. An alternative view is that the tissues use the immune system to maintain homeostasis by modulating immune cell phenotypes as necessary, probably via changing tissue environments which have the capacity to change immune cell phenotypes along the various stages of healing or persistent injury, the danger concept $[5,6]$.

Maintaining homeostasis is the ultimate goal of tissues in multicellular organisms and means maintaining tissue morphology as well as tissue function $[5,7]$. Only a few tissues, such as muscles and bones, can structurally adapt to distinct functional requirements whilst most tissues need to maintain their particular structure for full functionality, e.g. the brain, the kidney, the lung or heart. Traumatic, toxic, ischemic, metabolic, malignant or infectious injuries affect tissue structure and function. A view into less complex multicellular organisms including sponges, plants or worms teaches us that tissues have multiple ways of addressing such dangers $[8,9]$. Therefore, it is tempting to speculate that the growing complexity of danger responses provided throughout the evolu- tion of innate and adaptive immunity remains tightly controlled by the needs of tissue to maintain or regain homeostasis [6]. In this review we will summarize the various functions of the different tissue macrophage phenotypes as they are defined by changing tissue environments during the injury and repair phase of tissue damage.

\section{Tissue Needs for Regaining and Maintaining Homeostasis after Injury}

In most tissues resident macrophages or a network of interstitial dendritic cells continuously process foreign and self-antigens and present them to the $\mathrm{T}$ cell repertoire of the adaptive immune system (table 1) [10-12]. Under normal conditions autoantigen presentation senses tolerogenic signals for immune tolerance, i.e. a central element of tissue homeostasis [10]. Any kind of tissue injury affects tissue integrity by damaging parenchymal cells with some need for repair. Restoring tissue integrity when the injury is limited to the epithelial layer is often simple, achieved via compensatory proliferation of the surviving epithelial cells or local progenitors. For example, abrasion of the epidermis or acute renal tubular injury often heals quickly and can be mimicked experimentally with a scratch assay in monolayers of cultured epithelial cells $[13,14]$. However, nonsterile environments or more complex wounding involve other re- 
Table 2. The five phases of danger control

\begin{tabular}{|c|c|c|c|c|c|}
\hline & Clotting & Inflammation & $\begin{array}{l}\text { Epithelial } \\
\text { healing }\end{array}$ & $\begin{array}{l}\text { Mesenchymal } \\
\text { healing }\end{array}$ & Fibrolysis \\
\hline Time scale & Minutes & Hours to days & Days to weeks & Weeks to months & Months \\
\hline Danger to control & Bleeding & Sepsis & Chronic inflammation & Tissue instability & Fibrosis \\
\hline $\begin{array}{l}\text { Macrophage } \\
\text { contribution }\end{array}$ & $\begin{array}{l}\text { Secretion of tissue } \\
\text { factor promotes } \\
\text { coagulation }\end{array}$ & $\begin{array}{l}\text { Pathogen killing, secretion } \\
\text { of proinflammatory } \\
\text { mediators }\end{array}$ & $\begin{array}{l}\text { Secretion of anti-inflam- } \\
\text { matory mediators/ } \\
\text { growth factors }\end{array}$ & $\begin{array}{l}\text { Secretion of profi- } \\
\text { brotic mediators }\end{array}$ & $\begin{array}{l}\text { Protease secretion } \\
\text { and ECM } \\
\text { clearance }\end{array}$ \\
\hline
\end{tabular}

sponse mechanisms to address additional dangers to the host (table 2).

The first risk to control is that of fatal blood loss. Therefore, the injured tissue vasculature initiates a number of mechanisms to assure rapid clotting. The tissue environment at this stage is characterized by ischemia and the local release of multiple vasoactive molecules and platelet aggregates which massively release proinflammatory mediators including CC-and CXC-chemokines [15]. In this way coagulation already promotes inflammation, i.e. the second danger response program. Shortly after wounding, neutrophils enter the site of injury to prevent pathogen entry or spreading. However, the antimicrobial activity includes reactive oxygen species (ROS) production and enzyme release which also contributes to tissue damage, referred to as immunopathology or collateral damage [16]. During this phase the tissue environment is dominated by pathogen-associated molecular patterns (PAMPs) from microorganisms as well as by damage-associated molecular patterns (DAMPs) from dying parenchymal cells. PAMPs and DAMPs both activate innate pattern-recognition receptors of the resident immune cells as well as the infiltrating leukocytes for their full activation and proinflammatory phenotype [17]. Plateletderived growth factors and other as of yet poorly defined elements of the inflammatory response drive reepithelialization to restore the barrier to pathogen entry, a process that is of eminent importance to avoid persistent colitis [18]. The decreasing amount of DAMPs and PAMPs as well as the high number of apoptotic neutrophils represent a change in the tissue environment that promotes a different phenotype of tissue macrophages and the predominance of anti-inflammatory mediators as well as growth factors [16]. This environment will drive parenchymal healing and finally restoration of tissue integrity. However, if parenchymal repair is hampered, e.g. due to an insufficient capacity of local progenitors or persistent injuries, mesenchymal healing, i.e. fibrosis, will occur because the tissue environment remains dominated by growth factors that drive fibroblast proliferation and secretion of extracellular matrix (ECM) molecules $[19,20]$. At this stage microenvironments differ a lot within single organs in focal regions of sufficient or insufficient parenchymal repair, e.g. in liver cirrhosis, pulmonary fibrosis or focal segmental glomerulosclerosis of the kidney. Fibrotic tissues are largely ischemic and devoid of growth factors or cytokines. However, this can activate macrophages to release matrix metalloproteinase (MMPs) that have a capacity to remove the fibrous matrix resulting in the smallest possible scar area necessary $[13$, 21].

Macrophages contribute to most stages of the wound healing process as outlined in table 2 [22-25]. In the following sections we discuss how the different environments during the phases of tissue injury and repair determine tissue macrophage phenotypes and claim that macrophages are mainly amplifiers of their surrounding environment.

\section{Tissue Environments Dominated by PAMPs and/or DAMPs}

During infections PAMPs ligate Toll-like receptors (TLR) on tissue parenchymal cells and local dendritic cells leading to the secretion of proinflammatory cytokines and chemokines which create inflammatory tissue environments $[26,27]$. DAMPs have a similar potential to ligate TLRs, inflammasomes and other pattern-recognition receptors [17]. In fact, these receptors represent recognition platforms for infectious and sterile forms of danger that disrupt tissue homeostasis [28]. Activation 
of innate immunity subsequently involves the recruitment of leukocytes including macrophages as well as IFN- $\gamma$-secreting natural killer cells. Upon arrival the infiltrating macrophages become exposed to the PAMPand/or DAMP-rich environment. Macrophages are well equipped with pattern-recognition receptors [28, 29], hence PAMPs and DAMPs will lead to their full activation through a process similar to what has been referred to as 'classical-M1 macrophage activation' in in vitro studies [1]. Inflammatory macrophages secrete IL-1, IL12, IL-23, tumor necrosis factor (TNF)- $\alpha$ and ROS, and express inducible nitric oxide synthase (iNOS), major histocompatibility complex class II (MHCII ${ }^{\text {hi }}$ ), IL-1R, which mirrors what has been classified as an 'M1' macrophage by in vitro stimulation with IFN- $\gamma$, TNF- $\alpha$, lipopolysaccharide or granulocyte macrophage colony-stimulating factor (GM-CSF) [1]. This bactericidal macrophage phenotype appears in early phases of tissue injury shortly after the recruitment of neutrophils to enforce local host defense against pathogens. In PAMP-rich environments proinflammatory macrophages are potentially life-saving which outweighs the associated unspecific toxicity of the secreted mediators that cause collateral tissue damage [1, 16]. By contrast, in DAMP-rich but PAMP-free sterile injuries proinflammatory macrophages account for unnecessary tissue damage [30]. M1 macrophage polarization requires IFN-related factor (IRF) 5 for NF- $\mathrm{KB}$ signaling and subsequent secretion of proinflammatory cytokines and chemokines, ROS and other proinflammatory mediators which define the classically activated, proinflammatory (M1) macrophage phenotype [31]. Classically activated macrophages release MMPs to enable their migration through basement membranes and interstitial ECM networks. However, ECM digestion results in small ECM peptides and glycosaminoglycans which themselves can act as immunostimulatory DAMPs and fuel into the proinflammatory microenvironment [32].

As such the association of M1 macrophages with tissue inflammation is based on macrophage priming by PAMPs and DAMPs in the tissue. In turn, classically activated M1 macrophages further contribute to tissue inflammation and damage. Hence, such inflammatory macrophages amplify the tissue environment they found on arrival. This autoamplifying loop is necessary and continues until control of pathogen growth is achieved $[3,16]$. In PAMP-free sterile injuries the duration of this phase depends upon the trigger and can be short lasting, e.g. after transient ischemia reperfusion or toxin exposure [33]. By contrast, inflammation persists when ischemia or toxin exposure continues. For example, fetal dermal wound healing occurs in a sterile environment. Hence, much less proinflammatory macrophages are recruited to the site of injury which, besides the high proliferative capacity of the fetal epithelium, may be a reason why fetal wounds heal faster [34]. Also, keeping wounds sterile in adults is a way to keep them PAMP-free which limits the inflammatory response and promotes wound healing [13]. This can be mimicked in mouse models of sterile wounding. In the early phase of healing macrophages are completely dispensable, the depletion of these otherwise proinflammatory primed macrophages in fact ultimately leads to reduced scar areas [35]. Consistently, in situations of prolonged inflammation, unrestrained inflammatory macrophages severely impair wound healing. For example, erythrocyte-derived iron serves as a DAMP that, in the absence of any PAMP, primes the infiltrating macrophages towards an inflammatory phenotype that has, in the absence of any infection, detrimental effects on the healing [36]. However, some studies also document that the macrophage capacity for microbial killing can be indispensable. For example, wound closure and granulation tissue formation are significantly delayed upon early macrophage depletion, which could only be compensated by a subsequent influx of macrophages [35].

\section{DAMP-/PAMP-Rich Environments in Solid Organs}

The same biological program occurs inside solid organs, even though PAMPs are mostly absent in the heart, kidney, brain and glands [37-39]. These organs suffer from DAMP-driven proinflammatory macrophage infiltrates and the associated 'collateral damage' often outweighs the needs of tissue to restore homeostasis (table 3). Thus, blocking the recruitment or the activation of proinflammatory macrophages drastically reduces tissue damage and dysfunction in such sterile injuries. For example, a classically activated proinflammatory macrophage phenotype amplifies inflammation and loss of parenchymal cells in a variety of kidney diseases such as in anti-glomerular basement membrane glomerulonephritis [40], lupus nephritis [41-46], antigen-induced immune complex glomerulonephritis [47], renal allograft injury [48], ischemia reperfusion injury [33, 49-51] and adriamycin nephropathy [52]. The impact of in vivo macrophage reprogramming on disease outcomes has been demonstrated [53]. For example, Met-RANTES and AOPRANTES, two chemokine mutants, block macrophage recruitment but activate those tissue macrophages towards a proinflammatory phenotype which is sufficient to aggravate glomerular pathology in immune complex glomerulonephritis [47]. Vice versa, blocking the recruit- 


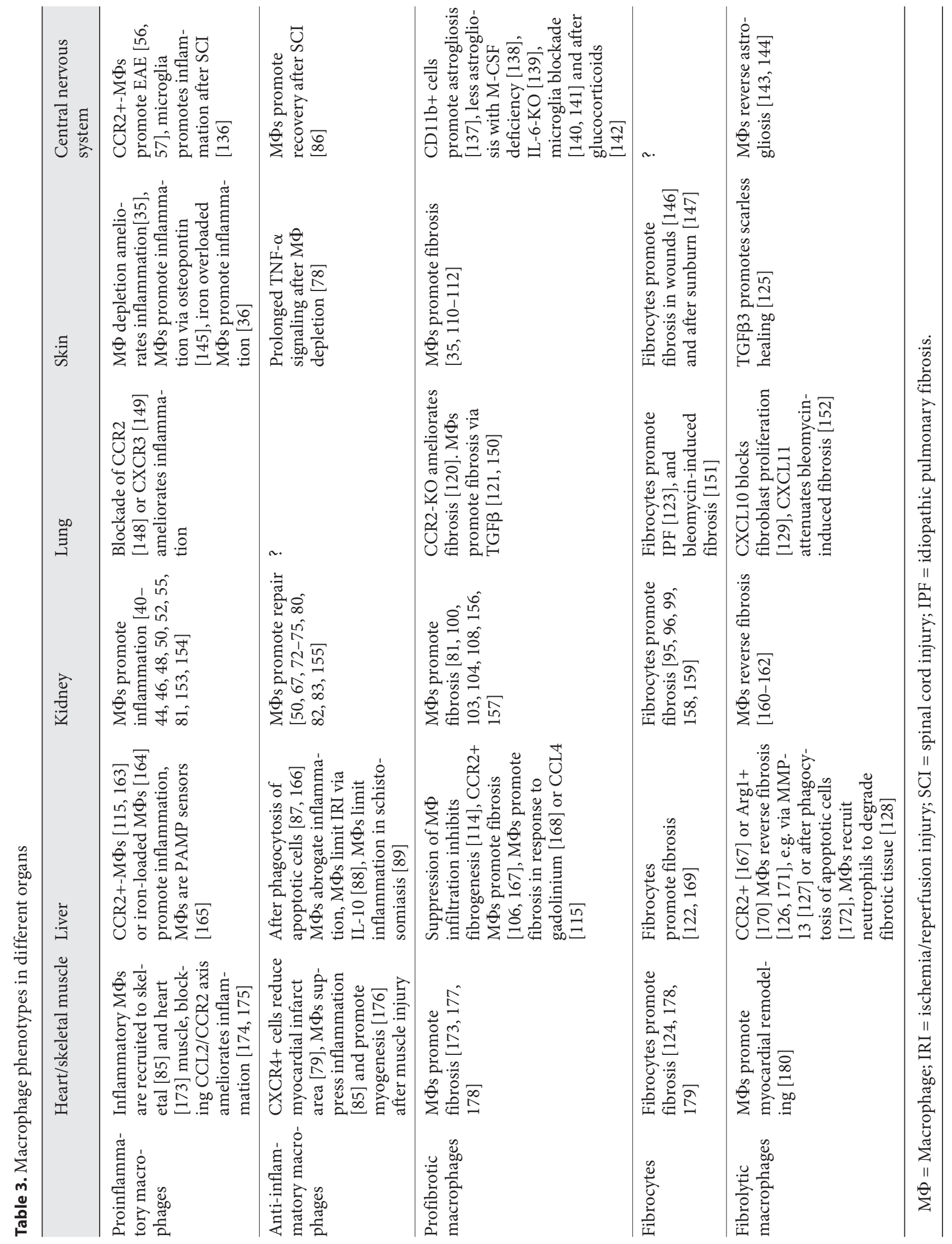


ment and activation of proinflammatory macrophages by interfering with the CC-chemokine ligand CCL2 and its chemokine receptor substantially reduces the numbers of proinflammatory macrophages in inflamed tissues, an effect that was shown to reduce immunopathology in a large number of inflammatory kidney disease models $[54,55]$. These observations do not only apply to the kidney, but also to autoimmune diseases of the central nervous system $[56,57]$. Infiltrating macrophages are crucial for the full phenotype of experimental autoimmune encephalitis (EAE) and impairment of macrophage recruitment by CCR2-knockout $(\mathrm{KO})$ strongly attenuated the EAE phenotype [57]. Similar data are available for CCl4induced liver injury and several other infectious and noninfectious types of inflammation in solid organs such as those listed in table 3. For example, the mucosal surfaces of the intestines resemble the PAMP-rich epithelial environment of skin, but there are also immunoprivileged sites in the gut $[7,58]$. There is a complex interplay of the gut flora, enterocytes and resident immune cells in which resident macrophages remain unresponsive to PAMPs from gut flora and danger signaling is rather provided by fully responsive infiltrating macrophage precursors, as recently reviewed elsewhere [59].

\section{Tissue Environments Dominated by Apoptotic Cells and Anti-Inflammatory Cytokines}

Some pathogens cannot be easily eliminated by IFN$\gamma$-driven innate immunity and Th1 T cell responses. For example, chronic helminth infections include repetitive life cycles of the parasite which involve ongoing damage to many different organs. During evolution Th2 responses developed to limit the growth of extracellular parasites and to provide permanent healing of persistent mucosal barrier injuries [60]. In this context downregulation of Th1 cytokines is linked to alternative macrophage activation involving Th2 cytokines like IL-4, IL-5, IL-10 and IL-13 [61, 62]. Triggering such responses is in the interest of the pathogen for sustained parasitism while they allow the host to somehow limit the consequences of persistent infection, inflammation and immunopathology [60].

We can find the same type of responses in other tissue abnormalities that lack pathogen entry or cell necrosis, like tumor environments, degenerative lesions or slowly accumulating toxins. These microenvironments are dominated by programmed forms of cell death such as apoptosis [63]. Apoptotic cell death and the clearance of apoptotic cells by macrophages are important elements of tissue homeostasis and immune tolerance, hence they are usually not associated with immune activation and can stimulate epithelial healing [63, 64]. In fact, apoptosis of activated neutrophils and $\mathrm{T}$ cells is a mechanism that prevents inappropriate or persistent immunopathology [64]. This becomes important also in postinflammatory phases of infections or sterile injuries. For example, transient ischemia/reperfusion is associated with cell necrosis, DAMP release followed by the influx of neutrophils and classically activated macrophages, but only for 2-3 days [33]. The microenvironment changes when the neutrophils undergo apoptosis and macrophages change their phenotype upon the excessive phagocytosis of apoptotic neutrophils which turns them into cells that release anti-inflammatory cy tokines such as transforming growth factor (TGF)- $\beta$ and IL-10 [65]. Serum amyloid-P, also named pentraxin-2, opsonizes apoptotic cells which further promotes the anti-inflammatory macrophage phenotype [66]. Immunosuppressive ('regulatory') T cells further promote the polarization towards anti-inflammatory macrophages via release of IL-10 and TGF- $\beta$ and by suppressing the response of $\mathrm{T}$ effector cells [67]. An integration of these different environmental signals for the deactivation of the macrophage occurs at the level of the transcription factor IRF4 which also acts as an intracellular competitor of IRF5, and thereby blocks TLR and IL-1R signaling [68-71]. Macrophage classifications that are based on in vitro studies have not yet integrated apoptotic cells as a stimulus of differentiation but the phenotype of cultured macrophages stimulated with IL-10 and TGF- $\beta$ (or glucocorticoids), referred to as the M2c type, shares similarities with anti-inflammatory macrophages (table 3) [1, 7277]. These cells themselves produce large amounts of IL10 illustrating that macrophages are able to amplify local environments by secreting similar cytokines in a feedforward loop [2]. Again dermal wound healing can serve as a paradigm for such non- or post-inflammatory tissue injuries [21]. Macrophage depletion from sterile wounds delays wound healing but also leads to severe hemorrhage, apoptosis of endothelial cells and detachment of the neuroepithelium from the dermis [35]. Thus, macrophages amplify the wound microenvironment for tissue stability as well as endothelial and epithelial repair. In addition, anti-inflammatory macrophages suppress inflammation in the wound because their depletion leads to increased and prolonged TNF- $\alpha$ expression inside the wound [78]. 
Postinflammatory Environments in Solid Organs

The same anti-inflammatory responses occur inside solid organs following transient sterile inflammation [64], such as ischemia/reperfusion (table 3). In the heart, where this phenomenon occurs during myocardial infarction, macrophages have been shown to be recruited [79] and improve myocardial remodeling [79]. After renal ischemia/reperfusion injury the phenotypic switch from proinflammatory towards anti-inflammatory macrophages is driven by tubular epithelial cell-derived factors as well as by the uptake of apoptotic neutrophils $[50,80]$. Lack of IRF4 enables macrophages to undergo this M1-M2 phenotype switch [69] and therefore the aggravated postischemic inflammation continues tubular cell necrosis [81]. In addition, direct IL-4/IL-10 treatment or genetically modified or transfused IL-10-stimulated macrophages help to resolve renal inflammation $[72-75,82]$. Steroid-based treatments seem to suppress kidney inflammation by inducing anti-inflammatory macrophages $[83,84]$. Even if initially recruited, monocytes display a proinflammatory phenotype and are rapidly primed towards anti-inflammatory capacities after injury in skeletal muscle tissue [85]. Anti-inflammatory macrophage functions are crucial for regeneration, as macrophage depletion leads to a significantly reduced diameter of the individual regenerating muscle fibers [85]. In the central nervous system, axonal regeneration after spinal cord injury is impaired upon depletion or blocking of the recruitment of macrophages [86]. In addition, their anti-inflammatory and therefore regenerative capacities were shown to be entirely IL-10-dependent. It is important to note that all these models involve sterile environments. Another example of healing during sterile organ dysfunction is toxic liver disease. $\mathrm{CCl}_{4}$ injection induces apoptosis of hepatocytes which are subsequently phagocytosed by Kupffer cells, which resembles efficient DAMP clearance and suppresses inflammation [87]. In hepatic ischemia/reperfusion injury IL-10 expression was crucial for anti-inflammatory capacities of macrophages [88]. In a PAMP- and DAMPdriven model of schistosomiasis liver injury, macrophage-specific deletion of the IL- $4 \mathrm{R} \alpha$ was accompanied by $100 \%$ mortality due to septicemia [89], which involves direct and indirect effects of IL-10 produced by alternatively activated macrophages in the gut and the liver, respectively [90]. Although this supports the importance of the anti-inflammatory capacities of macrophages, in contrast to sterile inflammation models, these properties were shown to be IL-10-independent. Taken together, these findings emphasize once more that it is the mi- croenvironment, in this case particularly the presence or absence of PAMPs, that is influenced by infiltrating or resident macrophages.

\section{Tissue Environments Dominated by Parenchymal Atrophy and Growth Factors}

Most body compartments have an enormous capacity for rapid and complete wound healing when the damage is limited to the epithelium and local progenitor cells survive the insult, and the repair is not compromised by infection or by persistent or remitting injuries [85]. The balance of factors that promote or compromise regeneration determine whether wound healing is rapid and scarless or delayed and associated with atrophy and fibrosis. In sterile injuries to mesenchymal structures the microenvironment is dominated by growth factors to promote tissue repair and scarring $[13,21]$. In fact, epithelial cells and noninflammatory macrophages are major sources of profibrotic cytokines [91]. In vitro, IL-4 and IL-13 induce STAT6 signaling to promote a macrophage phenotype that predominantly releases fibronectin and other ECM molecules and that expresses mannose and scavenger receptors, IL-1R11, FIZZ, and YM-1 [1]. These cells have been classified as M2a macrophages [1]. So far it is not clear whether anti-inflammatory and profibrotic macrophages can be clearly distinguished in vivo and it appears likely that macrophage plasticity creates a mixture or continuous variant shifts during wound healing [16]. Fibrocytes seem to represent the ultimate profibrotic macrophage that itself produces large amounts of collagen and shares phenotypic similarities with macrophages as well as fibroblasts [92-96]. The quantitative significance of this phenomenon remains under debate $[97,98]$. For example, green fluorescent protein lineage tracing using the collagen $1 \alpha 1$ promoter found this to be a rather rare phenomenon during renal fibrogenesis upon ureteral obstruction in mice [99]. The chemokine receptor CCR1 seems to be essential for the recruitment and activation of profibrotic macrophages and fibrocytes because a lack of CCR1 or CCR1 antagonism prevents progressive tissue fibrosis in many disease states and organs [100-109]. The first reports to document macrophages contributing to dermal fibrosis date back to the mid-seventies [110]. More recently, it has been shown that CXCR3+ macrophages might be the subset responsible for scar formation/fibrosis [111]. In a mouse model of diabetic chronic leg ulcer where scar formation regularly does not occur due to impaired macrophage activation, it can be induced by ad- 
ministering GM-CSF [112]. Interestingly, also in this setting in vivo conditions do not consistently match in vitro observations. According to the M1/M2 paradigm, profibrotic macrophages would be expected to be M2 polarized, whereas actually GM-CSF polarizes macrophages towards M1, and indeed fibrosis was found to be accompanied by an induction of proinflammatory cytokines within the wound [112]. As pointed out before, macrophage-mediated fibrosis (i.e. mesenchymal healing) represents a necessary step of fast and durable skin wound healing, but in sharp contrast to focal wounding of the skin or solid organs, it is detrimental in diffuse disease processes such as in progressive scleroderma or interstitial fibrosis of parenchymal tissues $[97,113]$.

\section{Solid Organ Fibrosis}

Progressive fibrosis and subsequent loss of solid organ function involves macrophages in multiple tissues (table 3). For example, decreased liver fibrosis was noted when macrophage infiltration was blocked by targeting the MCP-1/CCR2 axis $[114,115]$, as well as by deficiency in CCR1/CCR5 [106]. Some data are available for renal fibrosis $[100,103,104,116-119]$. In the lung CCR2 deficiency attenuated bleomycin-induced fibrosis [120], a process involving subsequent IL-13 signaling through IL-13-R $\alpha 1$ and IL-13-R $\alpha 2$ on macrophages to ultimately induce TGF- $\beta$ [121]. In addition to profibrotic macrophages, so-called fibrocytes, myofibroblasts of bone marrow origin, also contribute to fibrosis. This has been shown, amongst other sites, for the liver [122], the lung [123], the heart [124], as well as the kidney [20, 95] (table 3).

\section{Fibrotic Tissue Environments Dominated by ECM}

Organ fibrosis is characterized by loss of parenchymal cells and partial replacement by fibrous tissue, e.g. in progressive liver cirrhosis, lung fibrosis or renal interstitial fibrosis. However, fibrosis does not always lead to endstage organ failure [110]. More often fibrosis is a transient process to stabilize tissue integrity. For example, dermal wound healing ends in the smallest possible scar, like after a cut of the skin. Evidence for fibrolysis in the skin comes from recombinant TGF- $\beta 3$ application in humans as well as preclinical models [125] TGF- $\beta 3$ application prevents excessive proliferation of myofibroblasts and changes their migration towards a pattern normally seen only in the fetal stage where scarless healing occurs [125]. It remains to be proven exactly what role macrophages play in this process and so far little evidence is available on the macrophage phenotype in microenvironments dominated by the ECM.

\section{Evidence for Fibrolysis from Solid Organs}

Macrophages are capable of digesting ECM deposits via the secretion of selected MMPs which limit or even reverse fibrogenesis, e.g. in the kidney [125]. For example, macrophage depletion in the late phase of toxic liver fibrosis delays the clearance of liver scars [126], a process associated with MMP13 release by scar-associated macrophages [127]. Surprisingly, even at this stage of the disease macrophages recruit neutrophils to the liver which contribute to fibrotic matrix degradation [128]. In addition, antifibrotic macrophages are a possible source of CXCL10, a chemokine that, independent of ligation to its receptor, CXCR3, blocks the proliferation of fibroblasts in bleomycin-induced fibrosis [129]. It is therefore intriguing to speculate that a macrophage subtype with predominant fibrolytic activity exists in the ischemic environment of scar tissue that has the potential to digest ECM without concomitant secretion of proinflammatory cytokines (fig. 1). Surface markers that identify fibrolytic macrophages have not yet been described, but it should be technically feasible to isolate macrophages from fibrous lesions to characterize their phenotypic characteristics. Although the fibrolytic macrophage might be rare and hard to retrieve from fibrous lesions, it should be instrumental in understanding more about their potential to limit or to reduce tissue fibrosis. It is of note that MMPsecreting macrophages can also contribute to further tissue by degrading basement membranes and subsequent epithelial atrophy such as in the kidney [129]. Therefore, fibrolytic macrophages may also represent basement membrane-degrading macrophages which contribute to tissue atrophy. In fibrotic livers, however, transfer of bone marrow-derived macrophages has been shown to reverse hepatic fibrosis and to improve regeneration and function of the liver [129].

\section{Summary and Conclusions}

Macrophage plasticity gives rise to heterogeneous macrophage phenotypes in different and complex tissue environments and these, therefore, will never meet simplistic classifications. However, distinct tissue environments can induce prototypes of tissue macrophage phenotypes conceptually similar to those described in in vitro studies. For conceptual reasons we propose the clas- 


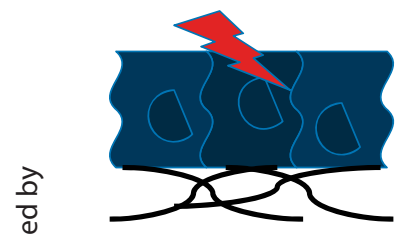

Cell necrosis

+/- infection

DAMPs/PAMPs

IFN- $\gamma$, TNF- $\alpha$

ROS

inflammatory

cytokines

chemokines

Proinflammatory

M1-like

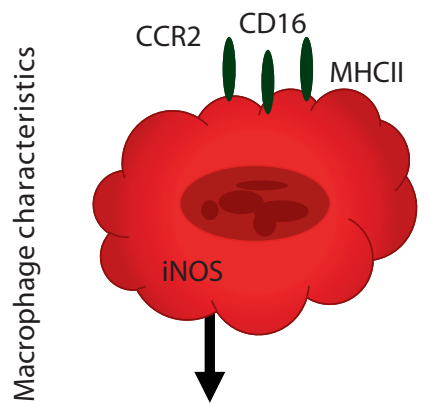

IL-1, IL-6, IL-12,

MMPs, MCP-1,

TNF- $\alpha$, ROS

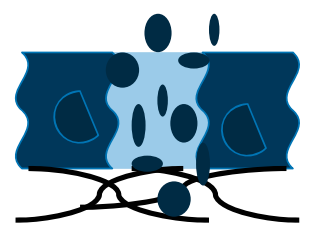

Apoptosis

Pentraxins

IL-10, IL-6

Lack of

homeostatic factors

Anti-inflammatory

M2c-like

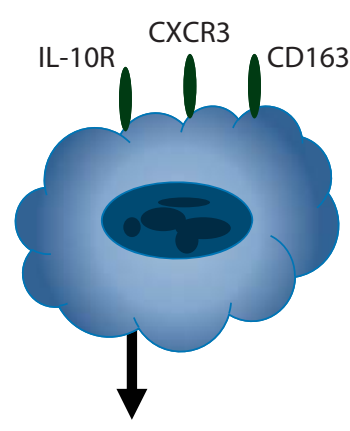

IL-10

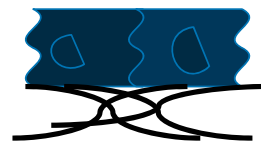

Epithelial atrophy

Growth factors:

TGF / CTGF

EGF / PDGF

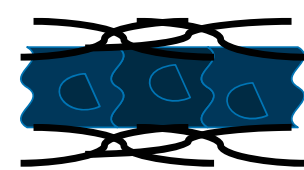

Fibrosis

Ischemia

Lack of growth

factors

Fibrolytic

ibrotic

M2a-like?

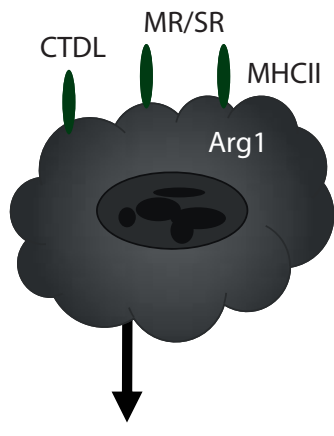

CTGF, TGF- $\beta$

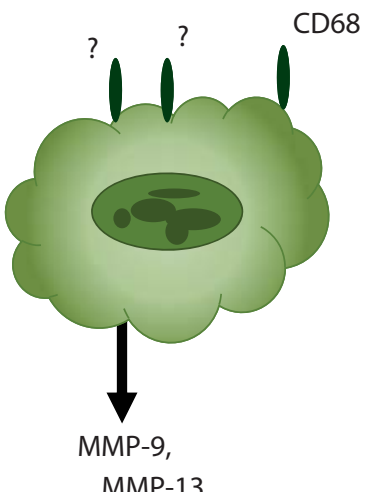

Fig. 1. Tissue microenvironments and predominant macrophage phenotypes. Acute tissue injury induces cell necrosis, hence the local microenvironment will be dominated by DAMPs. In nonsterile organs or during infections, PAMPs add to a tissue environment rich in factors that ligate pattern recognition receptors and drive macrophage polarization towards the M1-like proinflammatory phenotype. After the inflammatory response has cleared the sources of PAMPs and DAMPs, pentraxins and apoptotic cells, e.g. neutrophils, dominate the tissue environment which promotes macrophage polarization towards an anti-inflammatory M2-like phenotype that produces anti-inflammatory mediators which enrich the anti-inflammatory and proregenerative tissue environment. Once inflammation has completely ceased, the microenvi- ronment is dominated by growth factors that promote wound healing, especially in conditions of incomplete or insufficient epithelial repair. This environment drives macrophage polarization towards a profibrotic phenotype that contributes to the secretion of additional growth factors as well as ECM components. The ischemic environment of scar tissue is largely devoid of cytokine and growth factors which drives the few macrophages in place to predominately secrete proteases that have the potential to remove connective tissue, i.e. the fibrolytic macrophages. In vivo all four types of macrophages can coexist in different areas of the same organ with focal lesions of active inflammation, early and late repair, as well as scar formation. This needs to be considered while characterizing macrophage phenotypes from tissue biopsies. sification of tissue macrophages according to their predominant roles during the different stages of wound healing, a series of danger response programs that have been positively selected during the early evolution of multicellular organisms. As such, PAMP- and DAMP-rich (ne- crotic) environments prime proinflammatory (M1) macrophages that provide host defense but also inflammatory tissue damage. Postinflammatory environments including tumor stroma are dominated by apoptotic cells including neutrophils which induce a phenotype switch 
towards anti-inflammatory or tumor-associated macrophages that themselves suppress immunity and support epithelial growth, either healing or tumor growth. The environment of healing tissue, especially during insufficient epithelial healing, is dominated by growth factors that prime macrophages towards a profibrotic phenotype. Such macrophages themselves secrete profibrotic cytokines and ECM components fostering tissue scarring. Scar tissue is hypoxic and deprived of growth factors and cytokines which allows macrophages to predominantly secrete proteases that remove ECM, the fibrolytic macrophage. As such, macrophages are amplifiers of their surrounding environment, or so to say, the tissue 'uses' macrophages to stabilize and to reinforce the cur- rent environment. The same is true with dendritic cells and resident macrophages during homeostasis. Spatial and temporal variations of tissue environments occur especially after injury and during the different stages of tissue repair. These environmental changes are associated with changing macrophage phenotypes, but the chickenor-egg question remains to be further examined in each disease and each phase of the diseases.

\section{Acknowledgement}

This work was supported by grants from the Deutsche Forschungsgemeinschaft (AN372/11-1 and GRK 1202).

\section{References}

$>1$ Mantovani A, Sica A, Sozzani S, Allavena P, Vecchi A, Locati M: The chemokine system in diverse forms of macrophage activation and polarization. Trends Immunol 2004;25: 677-686.

$>2$ Mosser DM, Edwards JP: Exploring the full spectrum of macrophage activation. Nat Rev Immunol 2008;8:958-969.

$>3$ Gordon S, Taylor PR: Monocyte and macrophage heterogeneity. Nat Rev Immunol 2005;5:953-964.

-4 Medzhitov R: Origin and physiological roles of inflammation. Nature 2008;454:428-435.

$\checkmark 5$ Matzinger P: Friendly and dangerous signals: is the tissue in control? Nat Immunol 2007;8:11-13.

$\checkmark 6$ Matzinger P, Kamala T: Tissue-based class control: the other side of tolerance. Nat Rev Immunol 2011;11:221-230.

7 MacDonald TT, Monteleone I, Fantini MC, Monteleone G: Regulation of homeostasis and inflammation in the intestine. Gastroenterology 2011;140:1768-1775.

$>8$ Messier-Solek C, Buckley KM, Rast JP: Highly diversified innate receptor systems and new forms of animal immunity. Semin Immunol 2010;22:39-47.

$\checkmark 9$ Rast JP, Smith LC, Loza-Coll M, Hibino T, Litman GW: Genomic insights into the immune system of the sea urchin. Science 2006; 314:952-956.

10 Kapsenberg ML: Dendritic-cell control of pathogen-driven T-cell polarization. Nat Rev Immunol 2003;3:984-993.

-11 Stefater JA 3rd, Ren S, Lang RA, Duffield JS: Metchnikoff's policemen: macrophages in development, homeostasis and regeneration. Trends Mol Med 2011;17:743-752.

-12 Chorro L, Geissmann F: Development and homeostasis of 'resident' myeloid cells: the case of the Langerhans cell. Trends Immunol 2010;31:438-445.
13 Gurtner GC, Werner S, Barrandon Y, Longaker MT: Wound repair and regeneration. Nature 2008;453:314-321.

-14 Bonventre JV, Yang L: Cellular pathophysiology of ischemic acute kidney injury. J Clin Invest 2011;121:4210-4221.

15 Semple JW, Italiano JE Jr, Freedman J: Platelets and the immune continuum. Nat Rev Immunol 2011;11:264-274.

16 Galli SJ, Borregaard N, Wynn TA: Phenotypic and functional plasticity of cells of innate immunity: macrophages, mast cells and neutrophils. Nat Immunol 2011;12:1035-1044.

17 Rock KL, Latz E, Ontiveros F, Kono H: The sterile inflammatory response. Annu Rev Immunol 2010;28:321-342.

18 Rakoff-Nahoum S, Paglino J, Eslami-Varzaneh F, Edberg S, Medzhitov R: Recognition of commensal microflora by toll-like receptors is required for intestinal homeostasis. Cell 2004;118:229-241.

19 Lee SB, Kalluri R: Mechanistic connection between inflammation and fibrosis. Kidney Int Suppl 2010;119:S22-S26.

20 Anders HJ, Ryu M: Renal microenvironments and macrophage phenotypes determine progression or resolution of renal inflammation and fibrosis. Kidney Int 2011;80: 915-925.

21 Singer AJ, Clark RA: Cutaneous wound healing. N Engl J Med 1999;341:738-746.

22 Martin P, Leibovich SJ: Inflammatory cells during wound repair: the good, the bad and the ugly. Trends Cell Biol 2005;15:599-607.

23 Drake TA, Cheng J, Chang A, Taylor FB Jr: Expression of tissue factor, thrombomodulin, and E-selectin in baboons with lethal Escherichia coli sepsis. Am J Pathol 1993;142: 1458-1470.
24 Meisel SR, Xu XP, Edgington TS, Cercek B, Ong J, Kaul S, Shah PK: Dose-dependent modulation of tissue factor protein and procoagulant activity in human monocyte-derived macrophages by oxidized low density lipoprotein. J Atheroscler Thromb 2011;18: 596-603.

25 Chow A, Brown BD, Merad M: Studying the mononuclear phagocyte system in the molecular age. Nat Rev Immunol 2011;11:788798.

26 Kawai T, Akira S: Toll-like receptors and their crosstalk with other innate receptors in infection and immunity. Immunity 2011;34: 637-650.

27 Patole PS, Schubert S, Hildinger K, Khandoga S, Khandoga A, Segerer S, Henger A, Kretzler M, Werner M, Krombach F, Schlondorff D, Anders HJ: Toll-like receptor-4: renal cells and bone marrow cells signal for neutrophil recruitment during pyelonephritis. Kidney Int 2005;68:2582-2587.

28 Takeuchi O, Akira S: Pattern recognition receptors and inflammation. Cell 2010;140: 805-820.

29 Lech M, Avila-Ferrufino A, Skuginna V, Susanti HE, Anders HJ: Quantitative expression of rig-like helicase, nod-like receptor and inflammasome-related mRNAs in humans and mice. Int Immunol 2010;22:717728

30 Rock KL, Lai JJ, Kono H: Innate and adaptive immune responses to cell death. Immunol Rev 2011;243:191-205.

-31 Krausgruber T, Blazek K, Smallie T, Alzabin S, Lockstone H, Sahgal N, Hussell T, Feldmann M, Udalova IA: IRF5 promotes inflammatory macrophage polarization and TH1-TH17 responses. Nat Immunol 2011;12: 231-238. 
-32 Sorokin L: The impact of the extracellular matrix on inflammation. Nat Rev Immunol 2010;10:712-723.

-33 Swaminathan S, Griffin MD: First responders: understanding monocyte-lineage traffic in the acutely injured kidney. Kidney Int 2008;74:1509-1511.

- 34 Cowin AJ, Brosnan MP, Holmes TM, Ferguson MW: Endogenous inflammatory response to dermal wound healing in the fetal and adult mouse. Dev Dyn 1998;212:385393.

- 35 Lucas T, Waisman A, Ranjan R, Roes J, Krieg T, Muller W, Roers A, Eming SA: Differential roles of macrophages in diverse phases of skin repair. J Immunol 2010;184:3964-3977.

- 36 Sindrilaru A, Peters T, Wieschalka S, Baican C, Baican A, Peter H, Hainzl A, Schatz S, Qi Y, Schlecht A, Weiss JM, Wlaschek M, Sunderkotter C, Scharffetter-Kochanek K: An unrestrained proinflammatory M1 macrophage population induced by iron impairs wound healing in humans and mice. J Clin Invest 2011;121:985-997.

- 37 Anders HJ: Toll-like receptors and danger signaling in kidney injury. J Am Soc Nephrol 2010;21:1270-1274.

38 Benoit M, Desnues B, Mege JL: Macrophage polarization in bacterial infections. J Immunol 2008; 181:3733-3739.

-39 Kono H, Rock KL: How dying cells alert the immune system to danger. Nat Rev Immunol 2008;8:279-289.

40 Ikezumi Y, Atkins RC, Nikolic-Paterson DJ: Interferon-gamma augments acute macrophage-mediated renal injury via a glucocorticoid-sensitive mechanism. J Am Soc Nephrol 2003;14:888-898.

-41 Anders HJ, Vielhauer V, Eis V, Linde Y, Kretzler M, Perez de Lema G, Strutz F, Bauer S, Rutz M, Wagner H, Grone HJ, Schlondorff D: Activation of toll-like receptor-9 induces progression of renal disease in MRL-Fas(lpr) mice. FASEB J 2004;18:534536.

-42 Allam R, Pawar RD, Kulkarni OP, Hornung V, Hartmann G, Segerer S, Akira S, Endres S, Anders HJ: Viral 5'-triphosphate RNA and non-CpG DNA aggravate autoimmunity and lupus nephritis via distinct TLR-independent immune responses. Eur J Immunol 2008;38:3487-3498.

43 Patole PS, Grone HJ, Segerer S, Ciubar R, Belemezova E, Henger A, Kretzler M, Schlondorff D, Anders HJ: Viral doublestranded RNA aggravates lupus nephritis through toll-like receptor 3 on glomerular mesangial cells and antigen-presenting cells J Am Soc Nephrol 2005;16:1326-1338.

44 Patole PS, Pawar RD, Lichtnekert J, Lech M, Kulkarni OP, Ramanjaneyulu A, Segerer S, Anders HJ: Coactivation of toll-like receptor-3 and -7 in immune complex glomerulonephritis. J Autoimmun 2007;29:52-59.
Pawar RD, Patole PS, Ellwart A, Lech M, Segerer S, Schlondorff D, Anders HJ: Ligands to nucleic acid-specific toll-like receptors and the onset of lupus nephritis. J Am Soc Nephrol 2006;17:3365-3373.

46 Pawar RD, Patole PS, Zecher D, Segerer S, Kretzler M, Schlondorff D, Anders HJ: Tolllike receptor-7 modulates immune complex glomerulonephritis. J Am Soc Nephrol 2006; 17:141-149.

47 Anders HJ, Banas B, Linde Y, Weller L, Cohen CD, Kretzler M, Martin S, Vielhauer V, Schlondorff D, Grone HJ: Bacterial CpGDNA aggravates immune complex glomerulonephritis: role of TLR9-mediated expression of chemokines and chemokine receptors. J Am Soc Nephrol 2003;14:317-326.

48 Jose MD, Ikezumi Y, van Rooijen N, Atkins RC, Chadban SJ: Macrophages act as effectors of tissue damage in acute renal allograft rejection. Transplantation 2003;76:1015-1022.

49 Bonventre JV, Zuk A: Ischemic acute renal failure: an inflammatory disease? Kidney Int 2004;66:480-485.

50 Lee S, Huen S, Nishio H, Nishio S, Lee HK, Choi BS, Ruhrberg C, Cantley LG: Distinct macrophage phenotypes contribute to kidney injury and repair. J Am Soc Nephrol 2011;22:317-326

51 Lech M, Avila-Ferrufino A, Allam R, Segerer S, Khandoga A, Krombach F, Garlanda C, Mantovani A, Anders HJ: Resident dendritic cells prevent postischemic acute renal failure by help of single Ig IL-1 receptor-related protein. J Immunol 2009;183:4109-4118.

52 Wang Y, Cao Q, Zheng G, Lee VW, Zheng D, Li X, Tan TK, Harris DC: By homing to the kidney, activated macrophages potently exacerbate renal injury. Am J Pathol 2008;172: 1491-1499.

53 Wang Y, Harris DC: Macrophages in renal disease. J Am Soc Nephrol 2011;22:21-27.

54 Kulkarni O, Eulberg D, Selve N, Zollner S, Allam R, Pawar RD, Pfeiffer S, Segerer S, Klussmann S, Anders HJ: Anti-Ccl2 Spiegelmer permits $75 \%$ dose reduction of cyclophosphamide to control diffuse proliferative lupus nephritis and pneumonitis in MRLFas(lpr) mice. J Pharmacol Exp Ther 2009; 328:371-377.

55 Kulkarni O, Pawar RD, Purschke W, Eulberg D, Selve N, Buchner K, Ninichuk V, Segerer S, Vielhauer V, Klussmann S, Anders HJ: Spiegelmer inhibition of CCL2/MCP-1 ameliorates lupus nephritis in MRL-(Fas)lpr mice. J Am Soc Nephrol 2007;18:2350-2358.

56 King IL, Dickendesher TL, Segal BM: Circulating Ly- $6 c+$ myeloid precursors migrate to the CNS and play a pathogenic role during autoimmune demyelinating disease. Blood 2009;113:3190-3197.

57 Mildner A, Mack M, Schmidt H, Bruck W, Djukic M, Zabel MD, Hille A, Priller J, Prinz M: CCR2+Ly-6Chi monocytes are crucial for the effector phase of autoimmunity in the central nervous system. Brain 2009;132. 2487-2500.
8 Smith PD, Smythies LE, Shen R, GreenwellWild T, Gliozzi M, Wahl SM: Intestinal macrophages and response to microbial encroachment. Mucosal Immunol 2011;4:3142.

59 Mowat AM, Bain CC: Mucosal macrophages in intestinal homeostasis and inflammation. J Innate Immun 2011;3:550-564.

60 Allen JE, Wynn TA: Evolution of Th2 immunity: a rapid repair response to tissue destructive pathogens. PLoS Pathog 2011; 7:e1002003

61 Oliphant CJ, Barlow JL, McKenzie AN: Insights into the initiation of type 2 immune responses. Immunology 2011;134:378-385.

-62 Martinez FO, Helming L, Gordon S: Alternative activation of macrophages: an immunologic functional perspective. Annu Rev Immunol 2009;27:451-483.

63 Savill J, Gregory C, Haslett C: Cell biology: eat me or die. Science 2003;302:1516-1517.

64 Savill J: Apoptosis in resolution of inflammation. J Leukoc Biol 1997;61:375-380.

-65 Lucas M, Stuart LM, Savill J, Lacy-Hulbert A: Apoptotic cells and innate immune stimuli combine to regulate macrophage cytokine secretion. J Immunol 2003;171:26102615.

66 Duffield JS: Macrophages and immunologic inflammation of the kidney. Semin Nephrol 2010;30:234-254.

67 Liu G, Ma H, Qiu L, Li L, Cao Y, Ma J, Zhao Y: Phenotypic and functional switch of macrophages induced by regulatory CD4+CD25+ T cells in mice. Immunol Cell Biol 2010;89:130-142.

68 Negishi H, Ohba Y, Yanai H, Takaoka A, Honma K, Yui K, Matsuyama T, Taniguchi T, Honda K: Negative regulation of toll-likereceptor signaling by IRF-4. Proc Natl Acad Sci USA 2005;102:15989-15994.

69 Satoh T, Takeuchi O, Vandenbon A, Yasuda K, Tanaka Y, Kumagai Y, Miyake T, Matsushita K, Okazaki T, Saitoh T, Honma K, Matsuyama T, Yui K, Tsujimura T, Standley DM, Nakanishi K, Nakai K, Akira S: The Jmjd3Irf4 axis regulates $\mathrm{M} 2$ macrophage polarization and host responses against helminth infection. Nat Immunol 2010;11:936-944.

-70 El Chartouni C, Schwarzfischer L, Rehli M: Interleukin-4 induced interferon regulatory factor (Irf) 4 participates in the regulation of alternative macrophage priming. Immunobiology 2010;215:821-825.

71 Ishii M, Wen H, Corsa CA, Liu T, Coelho AL, Allen RM, Carson WF, Cavassani KA, Li X, Lukacs NW, Hogaboam CM, Dou Y, Kunkel SL: Epigenetic regulation of the alternatively activated macrophage phenotype. Blood 2009;114:3244-3254.

72 Cao Q, Wang Y, Zheng D, Sun Y, Lee VW, Zheng G, Tan TK, Ince J, Alexander SI, Harris DC: IL-10/TGF-beta-modified macrophages induce regulatory $\mathrm{T}$ cells and protect against adriamycin nephrosis. J Am Soc Nephrol 2010;21:933-942. 
73 Kluth DC, Ainslie CV, Pearce WP, Finlay S, Clarke D, Anegon I, Rees AJ: Macrophages transfected with adenovirus to express IL-4 reduce inflammation in experimental glomerulonephritis. J Immunol 2001; 166:47284736.

74 Wang Y, Wang YP, Zheng G, Lee VW, Ouyang L, Chang DH, Mahajan D, Coombs J, Wang YM, Alexander SI, Harris DC: Ex vivo programmed macrophages ameliorate experimental chronic inflammatory renal disease. Kidney Int 2007;72:290-299.

75 Zheng D, Wang Y, Cao Q, Lee VW, Zheng G, Sun Y, Tan TK, Alexander SI, Harris DC: Transfused macrophages ameliorate pancreatic and renal injury in murine diabetes mellitus. Nephron Exp Nephrol 2011;118:e87-e99.

-76 Barczyk K, Ehrchen J, Tenbrock K, Ahlmann M, Kneidl J, Viemann D, Roth J: Glucocorticoids promote survival of anti-inflammatory macrophages via stimulation of adenosine receptor A3. Blood 2010;116:446-455.

-77 Bertalan R, Patocs A, Vasarhelyi B, Treszl A, Varga I, Szabo E, Tamas J, Toke J, Boyle B, Nobilis A, Rigo J Jr, Racz K: Association between birth weight in preterm neonates and the BclI polymorphism of the glucocorticoid receptor gene. J Steroid Biochem Mol Biol 2008;111:91-94.

78 Mirza R, Di Pietro LA, Koh TJ: Selective and specific macrophage ablation is detrimental to wound healing in mice. Am J Pathol 2009; 175:2454-2462.

-79 Morimoto H, Takahashi M, Shiba Y, Izawa A, Ise $\mathrm{H}$, Hongo $\mathrm{M}$, Hatake $\mathrm{K}$, Motoyoshi $\mathrm{K}$, Ikeda U: Bone marrow-derived CXCR4+ cells mobilized by macrophage colony-stimulating factor participate in the reduction of infarct area and improvement of cardiac remodeling after myocardial infarction in mice. Am J Pathol 2007;171:755-766.

-80 Filardy AA, Pires DR, Nunes MP, Takiya CM, Freire-de-Lima CG, Ribeiro-Gomes FL, DosReis GA: Proinflammatory clearance of apoptotic neutrophils induces an IL-12(low) IL-10(high) regulatory phenotype in macrophages. J Immunol 2010;185:2044-2050.

-81 Lassen S, Lech M, Rommele C, Mittruecker HW, Mak TW, Anders HJ: Ischemia reperfusion induces IFN regulatory factor 4 in renal dendritic cells, which suppresses postischemic inflammation and prevents acute renal failure. J Immunol 2010;185:1976-1983.

-82 Huang XR, Kitching AR, Tipping PG, Holdsworth SR: Interleukin-10 inhibits macrophage-induced glomerular injury. J Am Soc Nephrol 2000;11:262-269.

-83 Ikezumi Y, Suzuki T, Karasawa T, Hasegawa $\mathrm{H}$, Kawachi H, Nikolic-Paterson DJ, Uchiyama M: Contrasting effects of steroids and mizoribine on macrophage activation and glomerular lesions in rat thy-1 mesangial proliferative glomerulonephritis. Am J Nephrol 2010;31:273-282.

84 Ghielli M, Verstrepen WA, Nouwen EJ, De Broe ME: Inflammatory cells in renal regeneration. Ren Fail 1996;18:355-375.
85 Arnold L, Henry A, Poron F, Baba-Amer Y, van Rooijen N, Plonquet A, Gherardi RK, Chazaud B: Inflammatory monocytes recruited after skeletal muscle injury switch into antiinflammatory macrophages to support myogenesis. J Exp Med 2007;204:10571069.

86 Shechter R, London A, Varol C, Raposo C, Cusimano M, Yovel G, Rolls A, Mack M, Pluchino S, Martino G, Jung S, Schwartz M: Infiltrating blood-derived macrophages are vital cells playing an anti-inflammatory role in recovery from spinal cord injury in mice. PLoS Med 2009;6:e1000113.

87 Shi J, Aisaki K, Ikawa Y, Wake K: Evidence of hepatocyte apoptosis in rat liver after the administration of carbon tetrachloride. Am J Pathol 1998;153:515-525.

88 Ren F, Duan Z, Cheng Q, Shen X, Gao F, Bai L, Liu J, Busuttil RW, Kupiec-Weglinski JW, Zhai Y: Inhibition of glycogen synthase kinase 3 beta ameliorates liver ischemia reperfusion injury by way of an interleukin-10mediated immune regulatory mechanism. Hepatology 2011;54:687-696.

89 Herbert DR, Holscher C, Mohrs M, Arendse B, Schwegmann A, Radwanska M, Leeto M, Kirsch R, Hall P, Mossmann H, Claussen B, Forster I, Brombacher F: Alternative macrophage activation is essential for survival during schistosomiasis and downmodulates $\mathrm{T}$ helper 1 responses and immunopathology. Immunity 2004;20:623-635.

90 Barron L, Wynn TA: Macrophage activation governs schistosomiasis-induced inflammation and fibrosis. Eur J Immunol 2011;41: 2509-2514.

91 Yang L, Besschetnova TY, Brooks CR, Shah JV, Bonventre JV: Epithelial cell cycle arrest in $\mathrm{G} 2 / \mathrm{M}$ mediates kidney fibrosis after injury. Nat Med 2010;16:535-543.

92 Quan TE, Cowper SE, Bucala R: The role of circulating fibrocytes in fibrosis. Curr Rheumatol Rep 2006;8:145-150.

93 Pilling D, Fan T, Huang D, Kaul B, Gomer $\mathrm{RH}$ : Identification of markers that distinguish monocyte-derived fibrocytes from monocytes, macrophages, and fibroblasts. PLoS One 2009;4:e7475.

94 Schmidt M, Sun G, Stacey MA, Mori L, Mattoli S: Identification of circulating fibrocytes as precursors of bronchial myofibroblasts in asthma. J Immunol 2003;171:380-389.

95 Niedermeier M, Reich B, Rodriguez Gomez M, Denzel A, Schmidbauer K, Gobel N, Talke Y, Schweda F, Mack M: CD4+ T cells control the differentiation of Gr1+ monocytes into fibrocytes. Proc Natl Acad Sci USA 2009; 106:17892-17897.

96 Sakai N, Furuichi K, Shinozaki Y, Yamauchi $\mathrm{H}$, Toyama T, Kitajima S, Okumura T, Kokubo S, Kobayashi M, Takasawa K, Takeda S, Yoshimura M, Kaneko S, Wada T: Fibrocytes are involved in the pathogenesis of human chronic kidney disease. Hum Pathol 2010;41: 672-678.
97 Zeisberg M, Neilson EG: Mechanisms of tubulointerstitial fibrosis. J Am Soc Nephrol 2010;21:1819-1834.

98 Grgic I, Duffield JS, Humphreys BD: The origin of interstitial myofibroblasts in chronic kidney disease. Pediatr Nephrol 2012;27:183-193.

-99 Lin SL, Kisseleva T, Brenner DA, Duffield JS: Pericytes and perivascular fibroblasts are the primary source of collagen-producing cells in obstructive fibrosis of the kidney. Am J Pathol 2008;173:1617-1627.

100 Anders HJ, Vielhauer V, Frink M, Linde Y, Cohen CD, Blattner SM, Kretzler M, Strutz F, Mack M, Grone HJ, Onuffer J, Horuk R, Nelson PJ, Schlondorff D: A chemokine receptor CCR-1 antagonist reduces renal fibrosis after unilateral ureter ligation. J Clin Invest 2002;109:251-259.

101 Bedke J, Kiss E, Schaefer L, Behnes CL, Bonrouhi M, Gretz N, Horuk R, DiedrichsMoehring M, Wildner G, Nelson PJ, Grone HJ: Beneficial effects of CCR1 blockade on the progression of chronic renal allograft damage. Am J Transplant 2007;7:527-537.

102 Blease K, Mehrad B, Standiford TJ, Lukacs NW, Kunkel SL, Chensue SW, Lu B, Gerard CJ, Hogaboam CM: Airway remodeling is absent in $\mathrm{CCR} 1^{-/-}$mice during chronic fungal allergic airway disease. J Immunol 2000;165:1564-1572.

103 Eis V, Luckow B, Vielhauer V, Siveke JT, Linde Y, Segerer S, Perez De Lema G, Cohen CD, Kretzler M, Mack M, Horuk R, Murphy PM, Gao JL, Hudkins KL, Alpers CE, Grone HJ, Schlondorff D, Anders HJ: Chemokine receptor CCR1 but not CCR5 mediates leukocyte recruitment and subsequent renal fibrosis after unilateral ureteral obstruction. J Am Soc Nephrol 2004;15: 337-347.

104 Ninichuk V, Anders HJ: Chemokine receptor CCR1: a new target for progressive kidney disease. Am J Nephrol 2005;25:365372.

105 Scholten D, Reichart D, Paik YH, Lindert J, Bhattacharya J, Glass CK, Brenner DA, Kisseleva T: Migration of fibrocytes in fibrogenic liver injury. Am J Pathol 2011;179: 189-198.

106 Seki E, de Minicis S, Inokuchi S, Taura K, Miyai K, van Rooijen N, Schwabe RF, Brenner DA: CCR2 promotes hepatic fibrosis in mice. Hepatology 2009;50:185-197.

107 Tokuda A, Itakura M, Onai N, Kimura H, Kuriyama T, Matsushima K: Pivotal role of CCR1-positive leukocytes in bleomycin-induced lung fibrosis in mice. J Immunol 2000;164:2745-2751.

108 Vielhauer V, Berning E, Eis V, Kretzler M, Segerer S, Strutz F, Horuk R, Grone HJ, Schlondorff D, Anders HJ: CCR1 blockade reduces interstitial inflammation and fibrosis in mice with glomerulosclerosis and nephrotic syndrome. Kidney Int 2004;66: 2264-2278. 
109 Yang Z, Kong B, Mosser DM, Zhang X: 120 Okuma T, Terasaki Y, Kaikita K, Kobayashi TLRs, macrophages, and NK cells: our understandings of their functions in uterus and ovary. Int Immunopharmacol 2011;11: $1442-1450$.

110 Leibovich SJ, Ross R: The role of the macrophage in wound repair. a study with hydrocortisone and antimacrophage serum. Am J Pathol 1975;78:71-100.

111 Ishida Y, Gao JL, Murphy PM: Chemokine receptor CX3CR1 mediates skin wound healing by promoting macrophage and fibroblast accumulation and function. J Immunol 2008;180:569-579.

-112 Fang Y, Shen J, Yao M, Beagley KW, Hambly BD, Bao S: Granulocyte-macrophage colony-stimulating factor enhances wound healing in diabetes via upregulation of proinflammatory cytokines. Br J Dermatol 2010;162:478-486.

$>113$ Lu TT: Dendritic cells: novel players in fibrosis and scleroderma. Curr Rheumatol Rep 2012;14:30-38.

-114 Imamura M, Ogawa T, Sasaguri Y, Chayama K, Ueno H: Suppression of macrophage infiltration inhibits activation of hepatic stellate cells and liver fibrogenesis in rats. Gastroenterology 2005;128:138-146.

115 Karlmark KR, Weiskirchen R, Zimmermann HW, Gassler N, Ginhoux F, Weber C, Merad M, Luedde T, Trautwein C, Tacke F: Hepatic recruitment of the inflammatory Gr1+ monocyte subset upon liver injury promotes hepatic fibrosis. Hepatology 2009;50:261-274.

-116 Vielhauer V, Anders HJ, Mack M, Cihak J, Strutz F, Stangassinger M, Luckow B, Grone HJ, Schlondorff D: Obstructive nephropathy in the mouse: progressive fibrosis correlates with tubulointerstitial chemokine expression and accumulation of CC chemokine receptor 2 - and 5-positive leukocytes. J Am Soc Nephrol 2001;12:11731187.

- 117 Kitagawa K, Wada T, Furuichi K, Hashimoto $\mathrm{H}$, Ishiwata $\mathrm{Y}$, Asano M, Takeya M, Kuziel WA, Matsushima K, Mukaida N, Yokoyama H: Blockade of CCR2 ameliorates progressive fibrosis in kidney. Am J Pathol 2004; 165:237-246.

- 118 Wada T, Furuichi K, Sakai N, Iwata Y, Kitagawa K, Ishida Y, Kondo T, Hashimoto H, Ishiwata Y, Mukaida N, Tomosugi N, Matsushima K, Egashira K, Yokoyama H: Gene therapy via blockade of monocyte chemoattractant protein-1 for renal fibrosis. J Am Soc Nephrol 2004;15:940-948.

-119 Ninichuk V, Clauss S, Kulkarni O, Schmid
H, Segerer S, Radomska E, Eulberg D, Buchner K, Selve N, Klussmann S, Anders $\mathrm{HJ}$ : Late onset of $\mathrm{Ccl} 2$ blockade with the spiegelmer mNOX-E36-3'PEG prevents glomerulosclerosis and improves glomerular filtration rate in $\mathrm{db} / \mathrm{db}$ mice. Am J Pathol 2008;172:628-637.
H, Kuziel WA, Kawasuji M, Takeya M: C-C chemokine receptor 2 (CCR2) deficiency improves bleomycin-induced pulmonary fibrosis by attenuation of both macrophage infiltration and production of macrophagederived matrix metalloproteinases. J Pathol 2004;204:594-604.

121 Fichtner-Feigl S, Strober W, Kawakami K, Puri RK, Kitani A: IL-13 signaling through the IL-13alpha2 receptor is involved in induction of TGF-betal production and fibrosis. Nat Med 2006;12:99-106.

122 Forbes SJ, Russo FP, Rey V, Burra P, Rugge M, Wright NA, Alison MR: A significant proportion of myofibroblasts are of bone marrow origin in human liver fibrosis. Gastroenterology 2004;126:955-963.

123 Andersson-Sjoland A, de Alba CG, Nihlberg K, Becerril C, Ramirez R, Pardo A, Westergren-Thorsson G, Selman M: Fibrocytes are a potential source of lung fibroblasts in idiopathic pulmonary fibrosis. Int J Biochem Cell Biol 2008;40:2129-2140.

124 van Amerongen MJ, Bou-Gharios G, Popa E, van Ark J, Petersen AH, van Dam GM, van Luyn MJ, Harmsen MC: Bone marrowderived myofibroblasts contribute functionally to scar formation after myocardial infarction. J Pathol 2008;214:377-386.

125 Occleston NL, O’Kane S, Laverty HG, Cooper M, Fairlamb D, Mason T, Bush JA, Ferguson MW: Discovery and development of avotermin (recombinant human transforming growth factor beta 3): a new class of prophylactic therapeutic for the improvement of scarring. Wound Repair Regen 2011;19(suppl 1):s38-s48.

126 Duffield JS, Forbes SJ, Constandinou CM, Clay S, Partolina M, Vuthoori S, Wu S, Lang R, Iredale JP: Selective depletion of macrophages reveals distinct, opposing roles during liver injury and repair. J Clin Invest 2005; 115:56-65.

127 Fallowfield JA, Mizuno M, Kendall TJ, Constandinou CM, Benyon RC, Duffield JS, Iredale JP: Scar-associated macrophages are a major source of hepatic matrix metalloproteinase-13 and facilitate the resolution of murine hepatic fibrosis. J Immunol 2007; 178:5288-5295.

128 Harty MW, Papa EF, Huddleston HM, Young E, Nazareth S, Riley CA, Ramm GA, Gregory SH, Tracy TF Jr: Hepatic macrophages promote the neutrophil-dependent resolution of fibrosis in repairing cholestatic rat livers. Surgery 2008;143:667-678.

129 Jiang D, Liang J, Campanella GS, Guo R, Yu S, Xie T, Liu N, Jung Y, Homer R, Meltzer EB, Li Y, Tager AM, Goetinck PF, Luster AD, Noble PW: Inhibition of pulmonary fibrosis in mice by CXCL10 requires glycosaminoglycan binding and syndecan-4. J Clin Invest 2010;120:2049-2057.

130 Crispe IN: Liver antigen-presenting cells. J Hepatol 2011;54:357-365.
31 Sathe P, Shortman K: The steady-state development of splenic dendritic cells. Mucosal Immunol 2008;1:425-431.

132 Welzen-Coppens JM, van Helden-Meeuwsen CG, Drexhage HA, Versnel MA: Abnormalities of dendritic cell precursors in the pancreas of the NOD mouse model of diabetes. Eur J Immunol 2012;42:186-194.

133 John R, Nelson PJ: Dendritic cells in the kidney. J Am Soc Nephrol 2007;18:26282635.

134 Nelson PJ, Rees AJ, Griffin MD, Hughes J, Kurts C, Duffield J: The renal mononuclear phagocytic system. J Am Soc Nephrol 2012; 23:194-203.

135 Ehninger A, Trumpp A: The bone marrow stem cell niche grows up: mesenchymal stem cells and macrophages move in. J Exp Med 2011;208:421-428.

136 Tian DS, Dong Q, Pan DJ, He Y, Yu ZY, Xie MJ, Wang W: Attenuation of astrogliosis by suppressing of microglial proliferation with the cell cycle inhibitor olomoucine in rat spinal cord injury model. Brain Res 2007;1154:206-214.

137 Leonardo CC, Eakin AK, Ajmo JM, Collier LA, Pennypacker KR, Strongin AY, Gottschall PE: Delayed administration of a matrix metalloproteinase inhibitor limits progressive brain injury after hypoxiaischemia in the neonatal rat. J Neuroinflammation 2008;5:34.

138 Raivich G, Moreno-Flores MT, Moller JC, Kreutzberg GW: Inhibition of posttraumatic microglial proliferation in a genetic model of macrophage colony-stimulating factor deficiency in the mouse. Eur J Neurosci 1994;6:1615-1618.

139 Cardenas H, Bolin LM: Compromised reactive microgliosis in MPTP-lesioned IL-6 KO mice. Brain Res 2003;985:89-97.

140 Tian DS, Xie MJ, Yu ZY, Zhang Q, Wang YH, Chen B, Chen C, Wang W: Cell cycle inhibition attenuates microglia induced inflammatory response and alleviates neuronal cell death after spinal cord injury in rats. Brain Res 2007;1135:177-185.

141 Raghavendra V, Tanga F, DeLeo JA: Inhibition of microglial activation attenuates the development but not existing hypersensitivity in a rat model of neuropathy. J Pharmacol Exp Ther 2003;306:624-630.

142 Spataro L, Dilgen J, Retterer S, Spence AJ, Isaacson M, Turner JN, Shain W: Dexamethasone treatment reduces astroglia responses to inserted neuroprosthetic devices in rat neocortex. Exp Neurol 2005;194: 289-300.

143 Rapalino O, Lazarov-Spiegler O, Agranov E, Velan GJ, Yoles E, Fraidakis M, Solomon A, Gepstein R, Katz A, Belkin M, Hadani M, Schwartz M: Implantation of stimulated homologous macrophages results in partial recovery of paraplegic rats. Nat Med 1998; 4:814-821. 
144 Ziv Y, Avidan H, Pluchino S, Martino G, 155 Castano AP, Lin SL, Surowy T, Nowlin BT, Schwartz M: Synergy between immune cells and adult neural stem/progenitor cells promotes functional recovery from spinal cord injury. Proc Natl Acad Sci USA 2006; 103:13174-13179.

145 Mori R, Shaw TJ, Martin P: Molecular mechanisms linking wound inflammation and fibrosis: knockdown of osteopontin leads to rapid repair and reduced scarring. J Exp Med 2008;205:43-51.

146 Mori L, Bellini A, Stacey MA, Schmidt M, Mattoli S: Fibrocytes contribute to the myofibroblast population in wounded skin and originate from the bone marrow. Exp Cell Res 2005;304:81-90.

- 147 Yang L, Scott PG, Dodd C, Medina A, Jiao H, Shankowsky HA, Ghahary A, Tredget EE: Identification of fibrocytes in postburn hypertrophic scar. Wound Repair Regen 2005; 13:398-404.

- 148 Belperio JA, Keane MP, Burdick MD, Lynch JP 3rd, Xue YY, Berlin A, Ross DJ, Kunkel SL, Charo IF, Strieter RM: Critical role for the chemokine MCP-1/CCR2 in the pathogenesis of bronchiolitis obliterans syndrome. J Clin Invest 2001;108:547-556.

- 149 Belperio JA, Keane MP, Burdick MD, Lynch JP 3rd, Xue YY, Li K, Ross DJ, Strieter RM: Critical role for CXCR3 chemokine biology in the pathogenesis of bronchiolitis obliterans syndrome. J Immunol 2002;169:10371049.

-150 Xing Z, Tremblay GM, Sime PJ, Gauldie J: Overexpression of granulocyte-macrophage colony-stimulating factor induces pulmonary granulation tissue formation and fibrosis by induction of transforming growth factor-beta 1 and myofibroblast accumulation. Am J Pathol 1997;150:59-66.

- 151 Atabai K, Jame S, Azhar N, Kuo A, Lam M, McKleroy W, Dehart G, Rahman S, Xia DD, Melton AC, Wolters P, Emson CL, Turner SM, Werb Z, Sheppard D: Mfge8 diminishes the severity of tissue fibrosis in mice by binding and targeting collagen for uptake by macrophages. J Clin Invest 2009;119: 3713-3722.

-152 Burdick MD, Murray LA, Keane MP, Xue YY, Zisman DA, Belperio JA, Strieter RM: CXCL11 attenuates bleomycin-induced pulmonary fibrosis via inhibition of vascular remodeling. Am J Respir Crit Care Med 2005; 171:261-268.

153 Ryu M, Kulkarni OP, Radomska E, Miosge N, Gross O, Anders HJ: Bacterial CpGDNA accelerates Alport glomerulosclerosis by inducing an M1 macrophage phenotype and tumor necrosis factor-alpha-mediated podocyte loss. Kidney Int 2011;79:189-198.

154 Anders HJ, Frink M, Linde Y, Banas B, Wornle M, Cohen CD, Vielhauer V, Nelson PJ, Grone HJ, Schlondorff D: CC chemokine ligand 5/RANTES chemokine antagonists aggravate glomerulonephritis despite reduction of glomerular leukocyte infiltration. J Immunol 2003;170:5658-5666.
Turlapati SA, Patel T, Singh A, Li S, Lupher ML Jr, Duffield JS: Serum amyloid P inhibits fibrosis through Fc gamma R-dependent monocyte-macrophage regulation in vivo. Sci Transl Med 2009;1:5ra13.

156 Ninichuk V, Khandoga AG, Segerer S, Loetscher P, Schlapbach A, Revesz L, Feifel R, Khandoga A, Krombach F, Nelson PJ, Schlondorff D, Anders HJ: The role of interstitial macrophages in nephropathy of type 2 diabetic $\mathrm{db} / \mathrm{db}$ mice. Am J Pathol 2007;170:1267-1276.

157 Dehmel S, Wang S, Schmidt C, Kiss E, Loewe RP, Chilla S, Schlondorff D, Grone HJ, Luckow B: Chemokine receptor Ccr5 deficiency induces alternative macrophage activation and improves long-term renal allograft outcome. Eur J Immunol 2010;40: 267-278.

158 Wada T, Sakai N, Sakai Y, Matsushima K, Kaneko S, Furuichi K: Involvement of bone-marrow-derived cells in kidney fibrosis. Clin Exp Nephrol 2011;15:8-13.

159 Broekema M, Harmsen MC, van Luyn MJ, Koerts JA, Petersen AH, van Kooten TG, van Goor H, Navis G, Popa ER: Bone marrow-derived myofibroblasts contribute to the renal interstitial myofibroblast population and produce procollagen I after ischemia/reperfusion in rats. J Am Soc Nephrol 2007;18:165-175.

160 Zeisberg M, Hanai J, Sugimoto H, Mammoto T, Charytan D, Strutz F, Kalluri R: BMP-7 counteracts TGF-betal-induced epithelial-to-mesenchymal transition and reverses chronic renal injury. Nat Med 2003; 9:964-968. grove D, Rougier JP, Werner MC, Shield CF 3rd, Werb Z, Kalluri R: Stage-specific action of matrix metalloproteinases influences progressive hereditary kidney disease. PLoS Med 2006;3:e100.

162 Nishida M, Okumura Y, Fujimoto S, Shiraishi I, Itoi T, Hamaoka K: Adoptive transfer of macrophages ameliorates renal fibrosis in mice. Biochem Biophys Res Commun 2005;332:11-16.

163 Marra F, DeFranco R, Grappone C, Parola M, Milani S, Leonarduzzi G, Pastacaldi S, Wenzel UO, Pinzani M, Dianzani MU, Laffi G, Gentilini P: Expression of monocyte chemotactic protein-1 precedes monocyte recruitment in a rat model of acute liver injury, and is modulated by vitamin E. J Investig Med 1999;47:66-75.

164 Otogawa K, Kinoshita K, Fujii H, Sakabe M, Shiga R, Nakatani K, Ikeda K, Nakajima Y, Ikura Y, Ueda M, Arakawa T, Hato F, Kawada N: Erythrophagocytosis by liver macrophages (Kupffer cells) promotes oxidative stress, inflammation, and fibrosis in a rabbit model of steatohepatitis: implications for the pathogenesis of human nonalcoholic steatohepatitis. Am J Pathol 2007;170: 967-980.
161 Zeisberg M, Khurana M, Rao VH, Cos-
65 Jiang W, Sun R, Wei H, Tian Z: Toll-like receptor 3 ligand attenuates LPS-induced liver injury by down-regulation of toll-like receptor 4 expression on macrophages. Proc Natl Acad Sci USA 2005;102:17077-17082.

166 Iredale JP, Benyon RC, Pickering J, McCullen M, Northrop M, Pawley S, Hovell C, Arthur MJ: Mechanisms of spontaneous resolution of rat liver fibrosis: hepatic stellate cell apoptosis and reduced hepatic expression of metalloproteinase inhibitors. J Clin Invest 1998;102:538-549.

167 Mitchell C, Couton D, Couty JP, Anson M, Crain AM, Bizet V, Renia L, Pol S, Mallet V, Gilgenkrantz H: Dual role of CCR2 in the constitution and the resolution of liver fibrosis in mice. Am J Pathol 2009;174:17661775 .

168 Ide M, Kuwamura M, Kotani T, Sawamoto $\mathrm{O}$, Yamate J: Effects of gadolinium chloride $(\mathrm{GdCl}(3))$ on the appearance of macrophage populations and fibrogenesis in thioacetamide-induced rat hepatic lesions. J Comp Pathol 2005;133:92-102.

169 Kisseleva T, Uchinami H, Feirt N, Quintana-Bustamante O, Segovia JC, Schwabe RF, Brenner DA: Bone marrow-derived fibrocytes participate in pathogenesis of liver fibrosis. J Hepatol 2006;45:429-438.

170 Pesce JT, Ramalingam TR, Mentink-Kane MM, Wilson MS, El Kasmi KC, Smith AM, Thompson RW, Cheever AW, Murray PJ, Wynn TA: Arginase-1-expressing macrophages suppress Th2 cytokine-driven inflammation and fibrosis. PLoS Pathog 2009;5:e1000371.

171 Thomas JA, Pope C, Wojtacha D, Robson AJ, Gordon-Walker TT, Hartland S, Ramachandran P, Van Deemter M, Hume DA, Iredale JP, Forbes SJ: Macrophage therapy for murine liver fibrosis recruits host effector cells improving fibrosis, regeneration and function. Hepatology 2011;53:20032015.

172 Popov Y, Sverdlov DY, Bhaskar KR, Sharma AK, Millonig G, Patsenker E, Krahenbuhl S, Krahenbuhl L, Schuppan D: Macrophage-mediated phagocytosis of apoptotic cholangiocytes contributes to reversal of experimental biliary fibrosis. Am J Physiol Gastrointest Liver Physiol 2010;298:G323G334.

173 Nahrendorf M, Swirski FK, Aikawa E, Stangenberg L, Wurdinger T, Figueiredo JL, Libby P, Weissleder R, Pittet MJ: The healing myocardium sequentially mobilizes two monocyte subsets with divergent and complementary functions. J Exp Med 2007;204:3037-3047.

174 Hayashidani S, Tsutsui H, Shiomi T, Ikeuchi M, Matsusaka H, Suematsu N, Wen J, Egashira K, Takeshita A: Anti-monocyte chemoattractant protein-1 gene therapy attenuates left ventricular remodeling and failure after experimental myocardial infarction. Circulation 2003;108:2134-2140. 
175 Hayasaki T, Kaikita K, Okuma T, Yamamoto E, Kuziel WA, Ogawa H, Takeya M: CC chemokine receptor-2 deficiency attenuates oxidative stress and infarct size caused by myocardial ischemia-reperfusion in mice. Circ J 2006;70:342-351.

176 Segawa M, Fukada S, Yamamoto Y, Yahagi H, Kanematsu M, Sato M, Ito T, Uezumi A, Hayashi S, Miyagoe-Suzuki Y, Takeda S, Tsujikawa K, Yamamoto H: Suppression of macrophage functions impairs skeletal muscle regeneration with severe fibrosis. Exp Cell Res 2008;314:3232-3244.
177 Leor J, Rozen L, Zuloff-Shani A, Feinberg MS, Amsalem Y, Barbash IM, Kachel E, Holbova R, Mardor Y, Daniels D, Ocherashvilli A, Orenstein A, Danon D: Ex vivo activated human macrophages improve healing, remodeling, and function of the infarcted heart. Circulation 2006;114:I94I100.

178 van Amerongen MJ, Harmsen MC, van Rooijen N, Petersen AH, van Luyn MJ: Macrophage depletion impairs wound healing and increases left ventricular remodeling after myocardial injury in mice. Am J Pathol 2007;170:818-829.
179 Haudek SB, Xia Y, Huebener P, Lee JM, Carlson S, Crawford JR, Pilling D, Gomer RH, Trial J, Frangogiannis NG, Entman ML: Bone marrow-derived fibroblast precursors mediate ischemic cardiomyopathy in mice. Proc Natl Acad Sci USA 2006;103: 18284-18289.

180 Hayashidani S, Tsutsui H, Ikeuchi M, Shiomi T, Matsusaka H, Kubota T, Imanaka-Yoshida K, Itoh T, Takeshita A: Targeted deletion of MMP-2 attenuates early LV rupture and late remodeling after experimental myocardial infarction. Am J Physiol Heart Circ Physiol 2003;285:H1229-H1235. 